Please do not remove this page

RMIT

UNIVERSITY

\title{
Characterisation of a uranium ore using multiple X-ray diffraction based methods
}

Reynolds, Hailey; Ram, Rahul; Charalambous, Fiona; Antolasic, Frank; Tardio, James; Bhargava, Suresh https://researchrepository.rmit.edu.au/esploro/outputs/9921857921001341/filesAndLinks?institution=61RMIT_INST\&index=null

Reynolds, H., Ram, R., Charalambous, F., Antolasic, F., Tardio, J., \& Bhargava, S. (2010). Characterisation of a uranium ore using multiple X-ray diffraction based methods. Minerals Engineering, 23(9), 739-745. https://doi.org/10.1016/j.mineng.2010.05.006

Document Version: Accepted Manuscript

Published Version: https://doi.org/10.1016/j.mineng.2010.05.006

Repository homepage: https://researchrepository.rmit.edu.au

(c) 2010 Pergamon-Elsevier Science Ltd

Downloaded On 2023/04/26 20:58:44 +1000 
Thank you for downloading this document from the RMIT Research Repository.

The RMIT Research Repository is an open access database showcasing the research outputs of RMIT University researchers.

RMIT Research Repository: http://researchbank.rmit.edu.au/

\section{Citation:}

Reynolds, H, Ram, R, Charalambous, F, Antolasic, F, Tardio, J and Bhargava, S 2010, 'Characterisation of a uranium ore using multiple $X$-ray diffraction based methods', Minerals Engineering, vol. 23, no. 9, pp. 739-745.

See this record in the RMIT Research Repository at:

http://researchbank.rmit.edu.au/view/rmit:17494

Version: Accepted Manuscript

Copyright Statement: (c) 2010 Pergamon-Elsevier Science Ltd

Link to Published Version:

http://dx.doi.org/10.1016/j.mineng.2010.05.006 


\title{
CHARACTERISATION OF A URANIUM ORE
}

\author{
Hailey S. Reynolds, Suresh Bhargava, Frank Antolasic, James Tardio \\ School of Applied Sciences, RMIT University \\ GPO Box 2476V, Melbourne, Vic, 3001, Australian \\ Email: h.reynolds@student.rmit.edu.au
}

\begin{abstract}
Uranium ores are often a complex mixture of minerals and compounds, a number of which are not of economic importance and are commonly referred to as gangue materials. In order to improve the efficiency of the dissolution stage of the overall uranium extraction process, a greater understanding of the minerals and compounds present in the ore is required. Detailed knowledge of the composition and types of uranium minerals present is important as the dissolution properties of uranium minerals can vary significantly. A greater knowledge of the gangue materials present is also important as these can have a significant effect on various aspects of the dissolution process, potential adsorption of aqueous uranium species and effects on the equilibria of aqueous uranium species. In this study the mineralogy of an untreated and pre-treated uranium ore was investigated using synchrotron and non-synchrotron X-ray diffraction. The results obtained from standard X-ray diffraction $(\mathrm{Cu}-\mathrm{K} \alpha)$ and synchrotron X-ray diffraction (16.534KeV) were compared and a number of minerals were identified. The improved spatial resolution and intensity of the synchrotron data allowed for superior phase identification of a variety of minerals where standard X-ray techniques gave inconclusive results. Various pre-treatment methods were also found to influence the identification of minerals in the ore.
\end{abstract}

\section{INTRODUCTION}

There are a number of uranium deposits around the world; however each deposit is substantially unique in terms of the uranium minerals present, the composition of these minerals and the influential surrounding gangue minerals (Ajuria et al., 1990). It is well established that many factors such as temperature, oxidation -reduction potential (ORP) and acid concentration have a significant effect on the dissolution of uranium from uranium ores. Gangue minerals are also recognised as having a significant affect on uranium dissolution. Some of the proposed effects of gangue minerals include alterations in uranium dissolution, degree of recovery and reactant consumption, and can be caused by a variety of factors (Laxen, 1972, Benes et al., 2001). Various cations are known to influence uranium extraction: Nesmeyanova and Alkhazashvili showed that $\mathrm{Fe}, \mathrm{Mn}, \mathrm{Cu}, \mathrm{Ni}, \mathrm{Co}$ and $\mathrm{V}$ could increase the uranium extraction and lower the acid concentration at which dissolution could occur (Nesmeyanova and Alkhazashvili, 1961). A further continuation of this is the influence various minerals have on the uranium chemistry. It was found that limonite and siderite could positively increase uranium extraction (Alkhazashvili et al., 1963). Though some minerals can act in a 
positive manner many uranium minerals are found as small inclusions in various gangue minerals. The ability to leach such uranium minerals then depends initially on its accessibility to the leachant, known as liberation, however this effect is not well understood (Lottering et al., 2008). If the uranium mineral is encapsulated in a mineral which is acid resistant this mineral will prevent the extraction of this portion of uranium.

To increase the effectiveness of the processes which are employed to extract valuable commodities such as uranium it is therefore important to understand the ore body in which the uranium is found. As the demand for uranium products increases a comprehensive understanding of an ore body is required to conduct fundamental research which may lead to great knowledge of current processes and enhance the ability to achieve complete uranium extraction. Synchrotron based techniques have been employed in a number of other mineral based problems and this technique was able to give outstanding results (Echard et al., 2008, Morsli et al., 2007, Valix and Cheung, 2002).

In order to gain a comprehensive understanding of gangue minerals and compounds on uranium dissolution accurate identification of all minerals and compounds in uranium ores is required.

Currently mineralogy is primarily conducted using multiple techniques such as automated mineralogical techniques coupled with elemental analysis. Though automated mineralogical techniques have revolutionised the way geologists and industry analyse samples, there are a number of limitations, especially when trying to characterise complex assemblages. The Mineral Liberation Analyser (MLA) system uses a combination of back-scattered electron (BSE) signals and X-ray analysis by comparing standard X-ray spectra of the unknown to identify the minerals. Though BSE images have a resolution of between $0.1 \mu \mathrm{m}$ and $0.2 \mu \mathrm{m}$, if the minerals have similar brightness only the X-ray analysis portion of the system can be used which has a resolution of between $2 \mu \mathrm{m}$ and $5 \mu \mathrm{m}$. MLA also uses a centroidal approach (Figure 1) whereby many phases maybe misclassified. Uranium minerals such as coffinite are known to exist as fine grade material and can cause incorrect characterisation in complex assemblages (Alphen, 2007, Goodall and Scales, 2007).

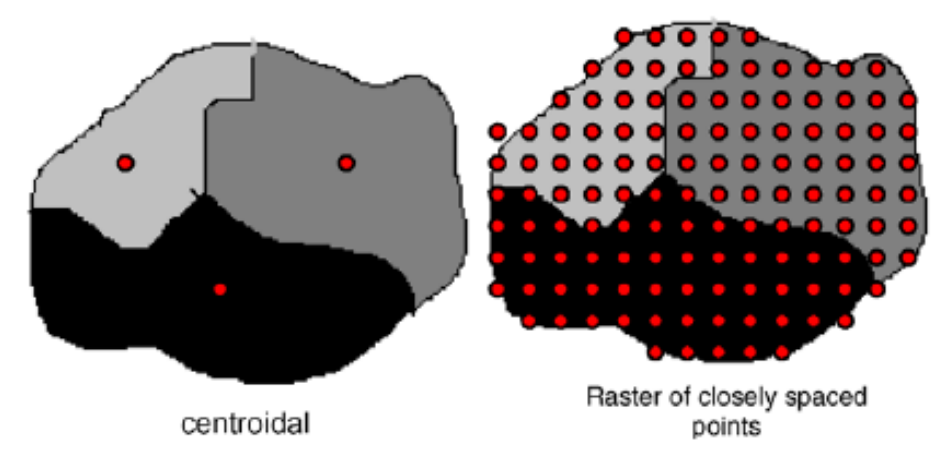


Fig.1: Electron beam positioning, centroidal and raster approaches QEMSCAN uses a combination of BSE and energy dispersive (EDS) X-ray spectra creating images using a raster approach (Fig. 1). Though this approach allows for greater phase identification throughout the sample, bias and misinterpretation of results may occur as the sequential mineral identification program requires a user to have preconceived ideas of the content of the sample and set up the instrument accordingly.

The aim of this study was to gain detailed information on the crystalline minerals and compounds present in a uranium ore and to compare the information obtained using standard X-ray diffraction and synchrotron X-ray diffraction.

\section{METHOD}

Standard X-ray diffraction patterns were obtained on a Bruker D8 Advance fitted with a Copper tube ( $\mathrm{Cu}$ Ka radiation). Diffraction patterns were run using a $1^{\circ}$ divergence slit, a step size of $0.015^{\circ}, 2.5 \mathrm{~s}$ per step and a total run time of $2.18 .55 \mathrm{Hr}$ at $40 \mathrm{Kv}$ and $35 \mathrm{~mA}$.

Synchrotron X-ray diffraction patterns were obtained using the X-ray diffraction instrument at the Australian Synchrotron using a photon energy of $16.5 \mathrm{KeV}$ and a beam current of $163 \mathrm{~mA}$. Each pattern was taken in two parts where the 2 theta was offset by $0.5^{\circ}$ with an acquisition time of 480s. These patterns were later merged together to produce the full pattern.

\section{RESULTS AND DISUCSSION}

The X-ray diffraction pattern obtained using the standard instrument is given in Fig. 2. The low intensity of the signals makes it difficult to distinguish minor phases from background noise in this diffraction pattern. The raised background synonymous with $\mathrm{X}$-ray amorphous material is due primarily to the polymer film which was used to cover the sample for safety reasons. The most significant peaks observed in the pattern are due to hematite $\left(\mathrm{Fe}_{2} \mathrm{O}_{3}\right)$ and quartz $\left(\mathrm{SiO}_{2}\right)$, denoted by $\wedge$ and $*$ respectively in Figure 2 . On closer analysis fluorite $\left(\mathrm{CaF}_{2}\right)$ was also able to be positively identified; however uraninite and bornite also appear around the fluorite peaks (Fig. 2 (Insert)) and may have contributed to the intensity of the major fluorite peak. 


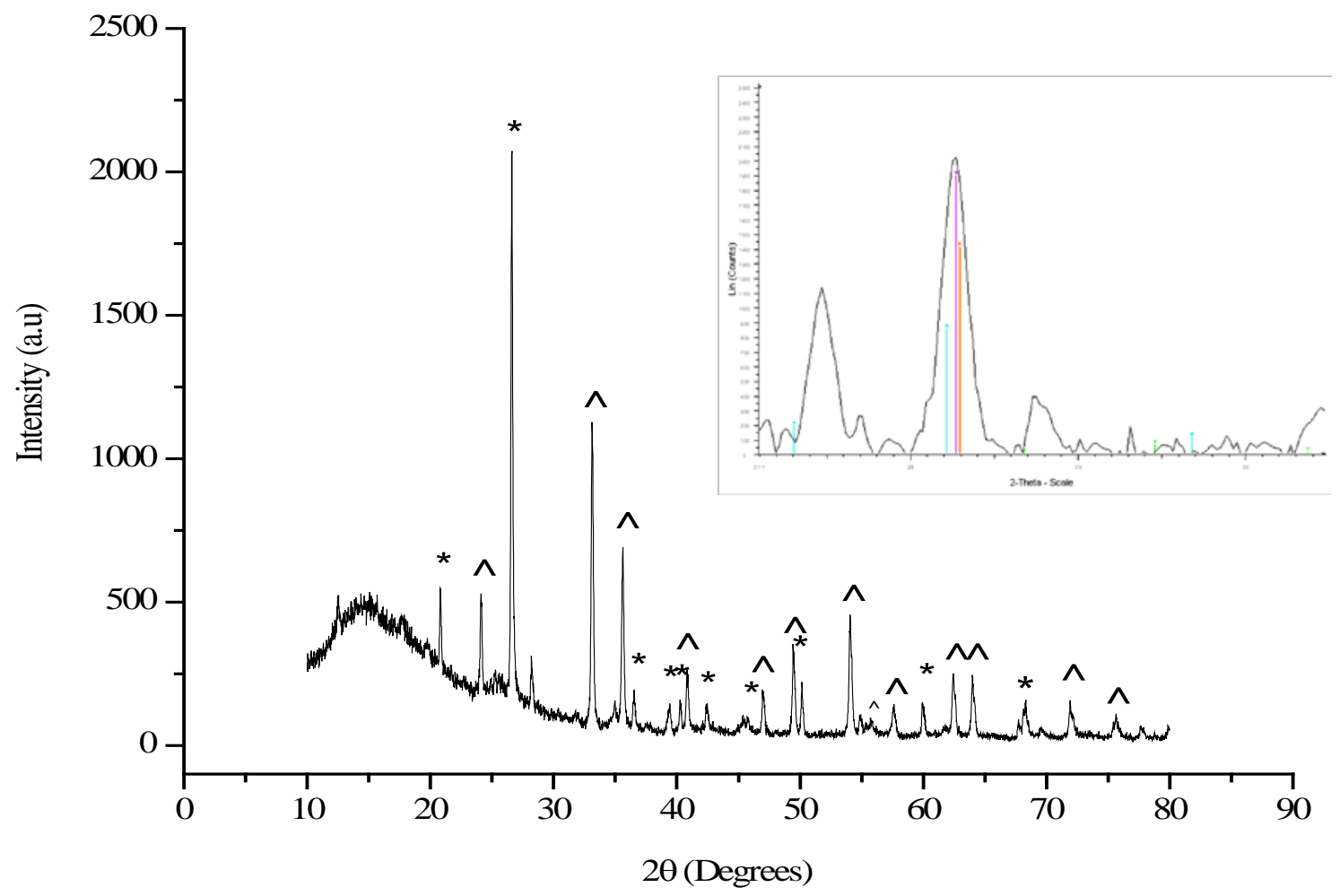

Fig. 2: RMIT X-ray diffraction pattern of ore $2 \theta$ range 10 to $80^{\circ} \mathrm{C}$ ( $\wedge$ hematite peaks *quartz peaks)

(Insert) $2 \theta$ range 27 to $30^{\circ}$ showing library matches of fluorite, bornite and uraninite (_ Fluorite _ Bornite Uraninite)

The smaller peaks which are almost indistinguishable from the background were studied and though no conclusive identification could be made, library matches suggested minerals such as sericite $\left(\mathrm{KAl}_{2}\left(\mathrm{Si}_{3} \mathrm{Al}\right) \mathrm{O}_{10}(\mathrm{OH}, \mathrm{F})_{2}\right.$ (Fig. 3), florencite $\left(\mathrm{CeAl}_{3}\left(\mathrm{PO}_{4}\right)_{2}(\mathrm{OH})_{6}\right)$, bornite $\left(\mathrm{Cu}_{5} \mathrm{FeS}_{4}\right)$, rutile $\left(\mathrm{TiO}_{2}\right)$, spinel group minerals and uraninite $\left(\mathrm{UO}_{2}\right)$ may have been present in the sample. Greater intensity and better resolution however would be required to identify and confirm the presence of these minerals via X-rav diffraction.

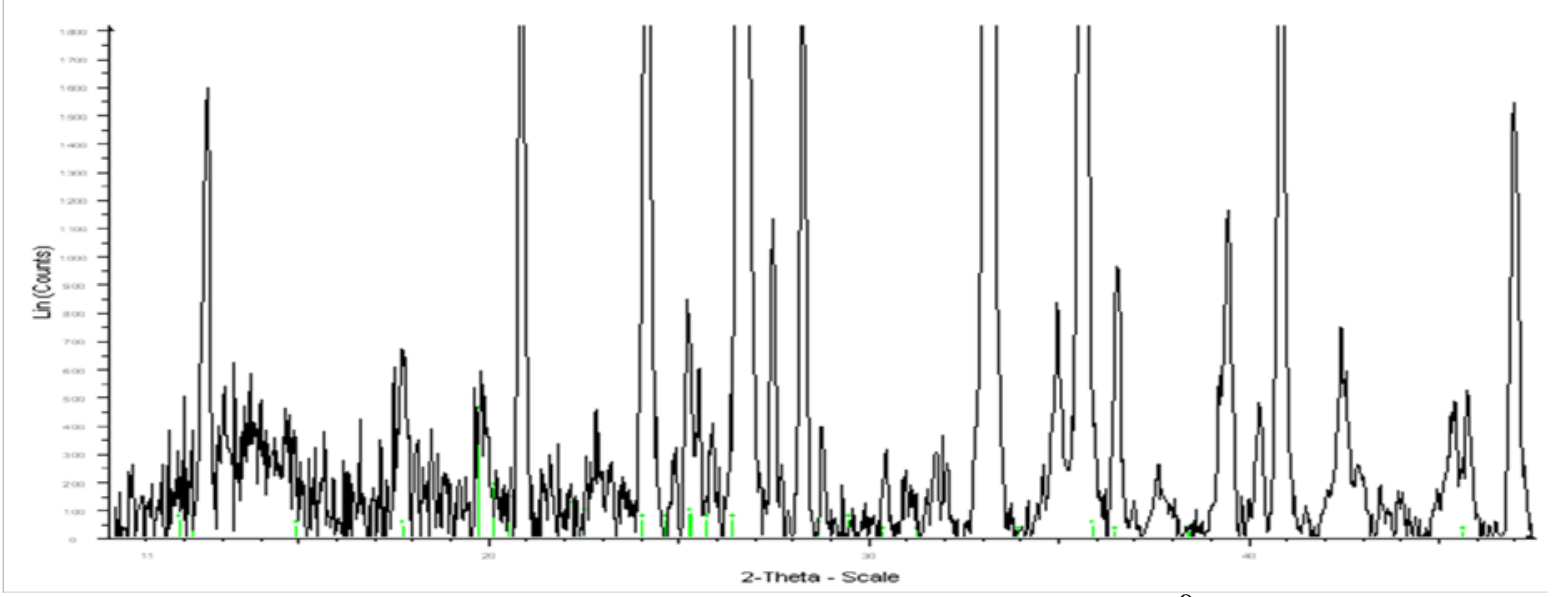

Fig. 3: RMIT X-ray diffraction pattern of ore from 10 to $50^{\circ} 2 \theta$ showing 
sericite library match (__ sericite)

The brilliance of the source at the Australian Synchrotron allowed for an enhanced data set. The increase in intensity and superior resolution were the key features allowing further characterisation of the ore to be possible. By comparing the two data sets (Fig.

4 ) it is clearly visible that the synchrotron data is much more powerful.

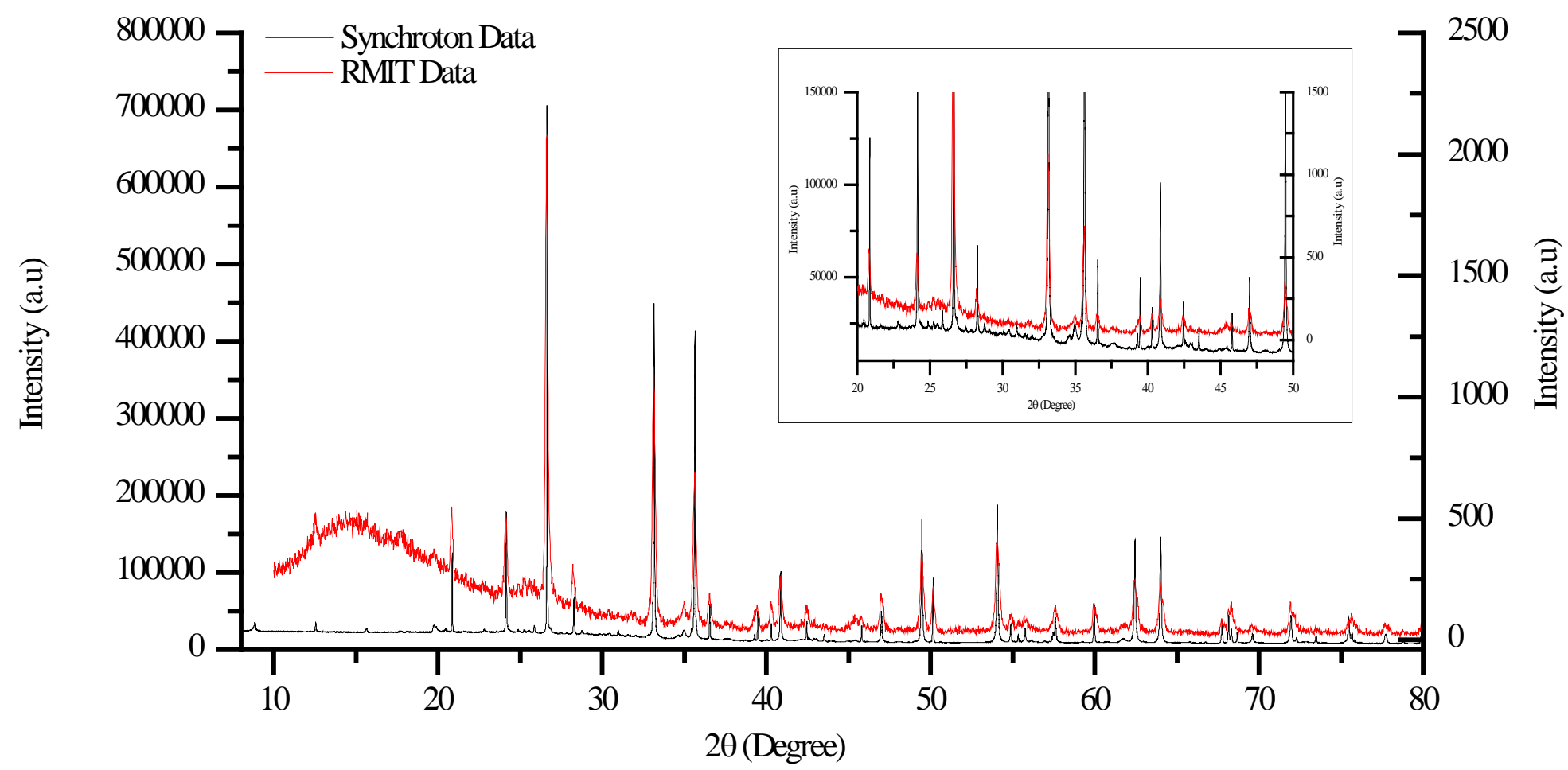

Fig. 4: RMIT X-ray diffraction pattern Vs Synchrotron X-ray diffraction pattern of ore from 10 to $80^{\circ} 2 \theta$ (Insert) expanded pattern from 20 to $50^{\circ} 2 \theta$

As would be expected the synchrotron data supports the identification of the major Xray active minerals, hematite, quartz and fluorite.

Sericite, rutile, spinel group minerals and uraninite, which the RMIT data suggested may be present, were found not to be present in this ore sample. The synchrotron data found that floencite, bornite, barite $\left(\mathrm{BaSO}_{4}\right)$, birnessite $\left(\mathrm{K}_{0.5} \mathrm{Mn}_{2} \mathrm{O}_{4.3}\left(\mathrm{H}_{2} \mathrm{O}\right)_{0.5}\right)$, siderite $\left(\mathrm{FeCO}_{3}\right)$, chalcopyrite $\left(\mathrm{CuFeS}_{2}\right)$, cuprospinel $\left(\mathrm{Cu}_{0.86} \mathrm{Fe}_{2.14} \mathrm{O}_{4}\right)$, alurgite $\left.\left(\mathrm{K}_{0.94} \mathrm{Na}_{0.06}\right)\left(\mathrm{Mg}_{0.08} \mathrm{Al}_{1.75} \mathrm{Fe}_{0.15} \mathrm{Mn}_{0.2}\right)\left(\mathrm{Al}_{0.9} \mathrm{Si}_{3.08}\right) \mathrm{O}_{10}(\mathrm{OH})_{2}\right)$, muscovite (K.Na) (Al,Mg,Fe $\left.)_{2}\left(\mathrm{Si}_{3.1} \mathrm{Al}_{0.9}\right) \mathrm{O}_{10}(\mathrm{OH})_{2}\right)$ and calcite $\left(\mathrm{CaCO}_{3}\right)$ were all present, though some only in trace quantities.

Because only small subsections of the ore have been used during the analysis at the synchrotron, three samples were prepared and analysed to observe any compositional variations that may occur if the sample is not homogenous as it was believed to be. It was found that XRD patterns of all three samples contained the same peaks and only varied slightly in intensity (Fig 5). 


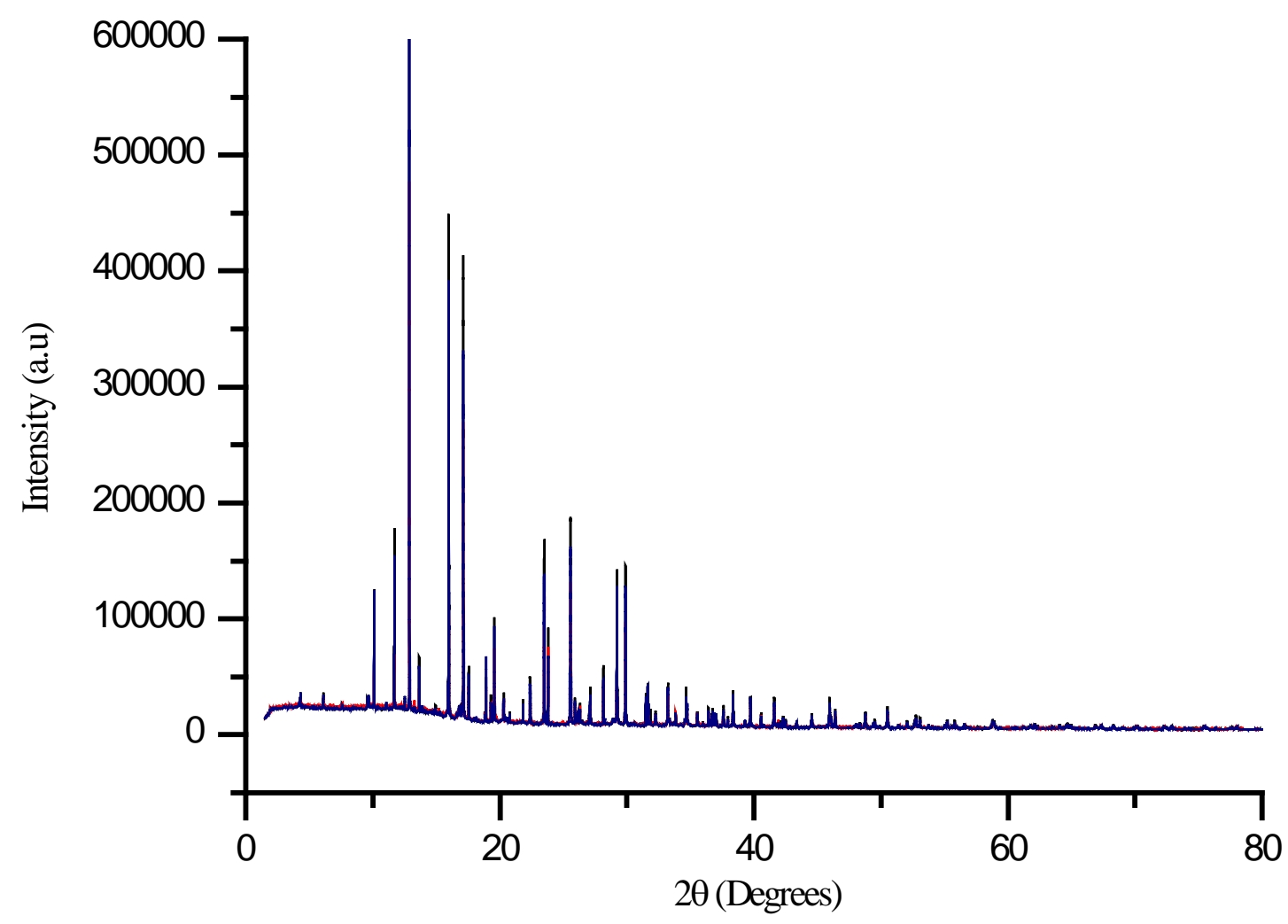

Fig. 5: Synchrotron X-ray diffraction pattern of three ore samples from 2 to $85^{\circ} 2 \theta$

It is not possible to have library matches for all phases which make up the ore due to the high complexity of the ore, many minerals that are isostructural with other minerals, the ability of elements to be exchanged with a variety of REE creating a large variation in composition of what could be a "simple" mineral and the inability to isolate and document each variant of each mineral.

This study also established that various pre-treatment methods altered the mineralogy of the ore. As can be seen in Fig. 6 any heat treatment of the ore produces significantly different diffraction patterns. Heating under either inert or reducing atmospheres was found to produce significantly similar diffraction patterns only differing in the intensity of various peaks, whereas heating in air showed the disappearance of various peaks, indicating the conversion of mineral phases to a more stable form. 


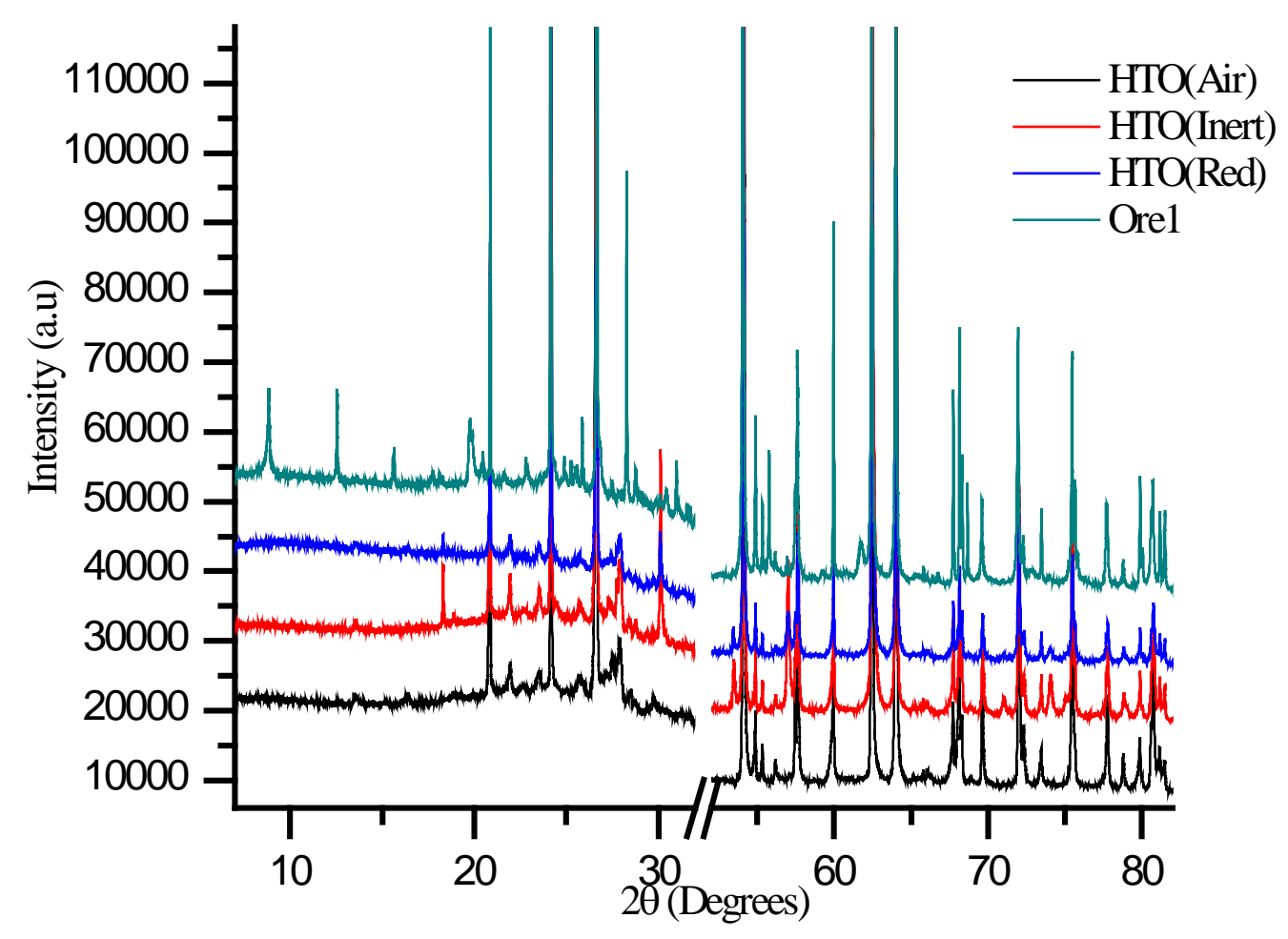

Fig. 6: Synchrotron X-ray diffraction data comparing the ore with ore heat treated in different environments.

\section{CONCLUSION}

This South Australian ore was found to contain large quantities of hematite and quartz, both of which were easily identified via standard X-ray diffraction. Fluorite was also found to be present in the ore in significant quantities based on standard X-ray diffraction results.

The improved spatial resolution and intensity of the synchrotron data allowed for superior phase identification of a variety of minerals where standard X-ray techniques gave inconclusive results. Synchrotron data allowed identification of minor phases including floencite, barite and birnessite with trace amounts of other minerals including rutile, siderite, chalcopyrite, cuprospinel, alurgite, muscovite and calcite.

Heat treatment of this ore was found to significantly alter the mineralogy, where treatment under air produced significantly different X-ray diffraction pattern than those ores treated under the either inert or reducing atmospheres.

Due to the trace levels of various minerals and plausible elemental substitution of many minerals X-ray diffraction data alone was not sufficient in identifying the mineralogy of such a complex assemblage. However the enhanced data obtained from the synchrotron 
has provided a greater understanding of the ore and will complement further analysis using other techniques.

\section{ACKNOWLEDGMENTS}

The authors would like to thank the Australian Research Council and BHP-Billiton for supporting this project through the Australian Research Council Linkage Projects scheme.

\section{REFERENCES}

AJURIA, S., JOE, E. G., MURTHY, T. K. S., PETERSON, H. D., SEIDEL, D. C. \& STERGARSEK, A. (1990) Manual on Laboratory Testing for Uranium ore processing. Technical Reports Series No. 313. Vienna, Inernational Atomic Energy Agency.

ALKHAZASHVILI, G. M., NESMEYANOVA, G. M. \& KUZ'MINA, L. N. (1963) The effect of the iron minerals in ores on oxidation of uranium in acid. Atomnaya Engergiya, 15, 313-317.

ALPHEN, C. V. (2007) Automated mineralogical analysis of coasl and ash products Challeneges and requirements. Minerals Engineering, 20, 496-505.

BENES, V., BOITSOV, A. V., FUZLULLIN, M., HUNTER, J., MAYS, W., NOVAK, J., SLEZAK, J., STOVER, D. E., TWEETON, D. \& UNDERHILL, D. H. (2001) Manual of acid in situ leach uranium mining technology. Vienna, Inernational Atomic Energy Agency.

ECHARD, J.-P., COTTE, M., DOORYHEE, E. \& BERTRAND, L. (2008) Insights into the varnishes of historical musical instruments using synchrotron microanalytical methods. Journal of Applied Physics A, 92, 77-81.

GOODALL, W. R. \& SCALES, P. J. (2007) An overview of the advantages and disadvantages of the determination of gold mineralogy by automated mineralogy. Minerals Engineering, 20, 506-517.

LAXEN, P. A. (1972) A fundamental study of the dissolution in acid solutions or uranium minerals from South African ores. Faculty of Engineering. Johannesburg, University of Witwatersrand.

LOTTERING, M. J., LORENZEN, L., PHALA, N. S., SMIT, J. T. \& SCHALKWYK, G. A. C. (2008) Mineralogy and uranium leaching response of low grade South African ores. Minerals Engineering 21, 16-22.

MORSLI, K., TORRE, A. G. D. L., STOBER, S., CUBEROS, A. J. M., ZAHIR, M. \& ARANDA, M. A. G. (2007) Quantitative Phase Analysis of Laboratory-Active Belite Clinkers by Synchrotron Powder Diffraction. Journal of American Ceramic Society, 90, 3205-3212.

NESMEYANOVA, G. M. \& ALKHAZASHVILI, G. M. (1961) The effect of certain compouds on the oxidation of uranium in acid media. Atomnaya Energiya, 10, 587-591.

VALIX, M. \& CHEUNG, W. H. (2002) Study of phase transformation of laterite ores at high temperature. Minerals Engineering, 15, 607-612. 